\title{
Design and Implementation of A Web Based Music Portal
}

\author{
F.B Abdullahi \\ Department of Mathematics \\ Ahmadu Bello University \\ Zaria - Nigeria
}

\author{
J. C Kisha \\ Department of Mathematics \\ Ahmadu Bello University \\ Zaria - Nigeria
}

\author{
T. Hassan \\ Faculty of Education \\ University of Abuja \\ Nigeria
}

\begin{abstract}
This study is aimed at developing a Web Based Music Portal which can be used to manage a musical library and a picture gallery. It is aimed to replace the manual system of getting musical CDs considering the technology advancement. The study discusses the World Wide Web (www) as an Internet service that allows the distribution of pages. Familiarity with web based application; web programming and web development as an industry are also discussed.It also consist the system analysis and design which include the several download and upload mechanisms. The system design, file and database design is given based on the detailed of the proposed system. The implementation and maintenance of the system comprises the software development, software testing and debugging as well as software implementation. The implementation of the system is done using Apache as web server with extended support for PHP and MYSQL.
\end{abstract}

\section{Keywords}

Web based and Music portal.

\section{INTRODUCTION}

The World Wide Web (WWW) has witnessed explosive growth over the past few years after its invention by Tim Berners-Lee in 1980. This is largely due to the new ways information has been created and used on the Internet. Consequently, the World Wide Web has become an important tool which can be adopted for various purposes [1]

The World Wide Web known as the Web, for short is a network of computers that are able to exchange text, graphics, and multimedia information via the Internet by sitting at a computer that is attached to the Web, using either a dial-up phone line or a much faster broadband (Ethernet, cable, or DSL connection), one can also visit Web-connected computers next door, at a nearby university, or halfway around the world. And one can take full advantage of the resources these computers make available, including text, graphics, videos, sounds, and animation. Think of the Web as the multimedia version of the Internet, and one will be right on the mark[4].

To understand the concept of the WWW, one needs to consider the concept of the Web as a large collection of documents. In its relatively short life, the Web has grown to host millions of sites and billions of pages. For the moment, think of each of these pages as a document. Many documents on the Web bear a strong similarity to the documents one meets in everyday life, and all documents have a structure, so think for a moment about the structure of some of the documents seen in everyday life.
A newspaper is made up of several stories or articles (and probably few captivating advertisements, too). Each story has a headline and then some paragraphs, perhaps a subheading and some paragraphs which may also include a picture or two [3].

The structure of articles on news Web sites is very similar to the structure of articles in newspapers. Each article is made up of headings, paragraphs of text, e.t.c. The only real difference is that each story gets its own page on a Web site, which is usually accessible from a headline and a brief summary either on the home page or the title pages for one of the subsections (such as the politics, sports, or entertainment sections).

\section{MUSIC AND THE INTERNET}

The advent of the Internet has transformed the experience of music partly through the increased ease of access to music and the increased choice. Chris Anderson, in his book The Long Tail: Why the Future of Business is Selling Less of More, suggests that while the economic model of supply and demand describes scarcity, the Internet retail model is based on abundance. Digital storage costs are low, so a company can afford to make its whole inventory available online, giving customers as much choice as possible. It has thus become economically viable to offer products that very few people are interested in. Consumers' growing awareness of their increased choice results in a closer association between listening tastes and social identity, and the creation of Thousands of niche markets. [5].

Another effect of the Internet arises with online communities like YouTube and MySpace. MySpace has made social networking with other musicians easier, and greatly facilitates the distribution of one's music. YouTube also has a large community of both amateur and professional musicians who post videos and comments. Professional musicians also use YouTube as a free publisher of promotional material. YouTube users, for example, no longer only download and listen to MP3s, but also actively create their own. According to Don Tapscott and Anthony D. Williams, in their book Wikinomics, there has been a shift from a traditional consumer role to what they call a "prosumer" role, a consumer who both creates and consumes. Music is made available on the internet using a technology called Web Database Application.

\section{PROBLEMS WITH EXISTING SYSTEM}

The problems faced by this system are numerous. Some of the problems surrounding the existing system include: 
a. Time consuming and Slow: A costumer has walk to a shop, get into an interview with the receptionist of what he/she wants before he/she starts looking for the song he/she wants.

b. Unsecure: Anyone operating this system stands a risk of losing the whole shop due to fires or robbery or the like.

c.Organization: The present system is not organized in a manner that it will be effective. This is due to the fact that there is no specified time for going round the store to look for what is needed.

d.The proposed system diminishes the effectiveness of the stores since the system is not organized when information about a particular item is needed or checking its availability; a lot of lengthy and time consuming procedures have to be followed to get the information required.[2]

\section{PROPOSED SYSTEM}

In web-based music portal, anyone interested in buying musical CDs can just sit in the comfort of wherever he/she is and download whatsoever song he/she wishes. The buyer can search for songs based on the name of the artist, album in which the song was sang, or the name of the song itself. Even if the user misspells the song, forgets the album title or doesn't know the song artist, options will be given so that he/she can get what he/she wants.

Web Based Music Portal would be managed by an administrator. Thus there would be two different classes of users logging on to the site. One is the shop user looking for a song or songs, and then the administrator who controls the whole process.

\section{WEB DATABASE APPLICATION}

An application is a program or a group of programs designed for use by an end user. If the end user interacts with the application via a Web browser, the application is a Web-based or Web application. If the Web application requires the longterm storage of information, using a database, it is a Web database application.[7]

A Web database application is designed to help a user accomplish a task. It can be a simple application that displays information in a browser window (for example, it displays current job openings when the user selects a job title) or a complicated program with extended functionality (for example, the book-ordering application at Amazon.com or the bidding application at eBay). Not surprisingly, a Web database application consists of a database and an application just two piece.[6].

\subsection{Application}

The application piece is the program or group of programs that performs the tasks. Programs create the display that the user sees in the browser window. They make your application interactive by accepting and processing information that the user types in the browser Web server will send a default Web page). The browser asks a domain name server to translate the domain name you requested into an IP address. The browser then sends a request to that server for the page you want, using a standard called Hypertext Transfer Protocol or HTTP (hence the http:// seen at the start of many Web addresses).

The server should constantly be connected to the Internet and ready to serve pages to visitors. When it receives a request, it looks for the requested document and returns it. When a request is made, the server usually logs the client's IP address, the document requested, and the date and time it was requested.[5]

An average Web page actually requires the Web browser to request more than one file from the Web server and not just the XHTML page, but also any images, style sheets, and other resources in the page. Each of these files including the main page needs a URL (a Uniform Resource Locator) to identify it. A URL is a unique address on the Web where that page, picture, or other resource can be found and is made up of the domain name (for example, wrox.com), the name of the folder or folders on the Web server that the file stays in (also known as directories on a server), and the name of the file itself. After the browser acquires the files it then inserts the images and other resources in the appropriate place to display the page. The Web pages created with HTML alone are static, meaning the user can't interact with the Web page. All users see the same Web page. Dynamic Web pages, on the other hand, allow the user to interact with the Web page. Different users might see different Web pages. For instance, one user looking at a furniture store's online product catalog might choose to view information about the sofas, whereas another user might choose to view information about coffee tables.

One language widely used to make Web pages dynamic is JavaScript. JavaScript is useful for several purposes, such as mouse-overs (for example, to highlight a navigation button when the user moves the mouse pointer over it) or accepting and validating information that users type into a Web form.[5]

Another aspect of Web programming is the Server-side programming in which languages like PHP, asp.net, JSP etc are used. For the sake of this project, we shall be using PHP. PHP however, is a language that is particularly well suited to interact with databases. PHP can accept and validate the information that users type into a Web form and can also move the information into a database.

PHP, a scripting language designed specifically for use on the Web, is a dynamic tool for creating dynamic Web pages. PHP is rich in features that make Web design and programming easier. PHP is in use on over 13 million domains (according to the Netcraft survey at www.php.net/usage.php). Its popularity continues to grow, meaning that it fulfils its function pretty well.

PHP stands for PHP: HyperText Preprocessor. In its early development by a guy named Rasmus Lerdorf, it was called Personal Home Page tools. When it was developed into a fullblown language, the name was changed to be more in line with its expanded functionality. The PHP language's syntax is similar to the syntax of $\mathrm{C}$, so if you have experience with $\mathrm{C}$, you'll be comfortable with PHP. PHP is actually simpler than $\mathrm{C}$ because it does not use some of the more difficult concepts of C. PHP also doesn't include the low-level programming capabilities of $\mathrm{C}$ because PHP is designed to program Web sites and doesn't require those capabilities. PHP is particularly strong in its ability to interact with databases. PHP supports more databases ever heard of (and some haven't of). PHP handles connection to database and communicate with it. One does not need to know the technical details for connecting to a database or for exchanging messages with it. What one need to do is to tell PHP the name of the database and where it is, and PHP handles the details. It connects to the database, passes instructions to the database, and returns the database response. Technical support is available for PHP. One can join several email discussion lists offered on the PHP Web site (www.php.net), including a list for databases and PHP. In 
addition, a Web interface discussion lists is available at news.php.net where one can browse or search the messages.

\section{MATERIALS AND METHODS}

An online music portal system will be designed and implemented using MySQL as the database, Apache will be web server to provide basic functionality of the web services.PHP will be used as scripting language to program the server side that manipulates the knowledge in the database.

\section{ARCHTECTURAL DESIGN}

The factors considered in designing the online music portal system are Interoperability and accessibility with minimum requirements on the user's side. Due to large flow of information delivery over the Internet, the system is implemented as a standard Internet application. The client side requires no more than standard Internet browser installed on the local computer, while the main application functionality is assured by the server side. Figure 3.4 illustrate E-health System Architecture.

This includes, user interface made up of access services points (shown as client system below) at the remote site, a high speed, highly reliable and scalable regional network and content management gateway with database server. This architecture allow users to access the system via the Internet using hypertext transfer protocol and the user request is transformed into a structured query language using a PHP common content management gateway, which in turn passes it to the appropriate backend system. The common content management gateway provides a single point entry to the system

\section{IMPLEMENTATION AND RESULT}

The Web Based Music Portal System has seven different tables. The tables contained in the database are:

\subsection{Users}

This table contains information about users like user names, email, sex, password to login into the site, sign up date, nationality, e.t.c. The underlined attribute is the primary key.

Table 1: Users

\begin{tabular}{|c|c|c|c|}
\hline Field & Type & Collation & Null \\
\hline userid & $\operatorname{Int}(25)$ & $\begin{array}{c}\text { Latin1_swedis } \\
\mathrm{h} \text { dd }\end{array}$ & No \\
\hline $\begin{array}{c}\text { First_nam } \\
\mathrm{e}\end{array}$ & $\begin{array}{l}\operatorname{varchar}(2 \\
5)\end{array}$ & $\begin{array}{c}\text { Latin1_swedis } \\
\text { h_d }\end{array}$ & No \\
\hline last_name & $\begin{array}{l}\operatorname{varchar}(2 \\
5)\end{array}$ & $\begin{array}{c}\text { Latin1_swedis } \\
\text { h_d }\end{array}$ & No \\
\hline $\begin{array}{c}\text { email_add } \\
\text { re }\end{array}$ & $\begin{array}{l}\operatorname{varchar}(2 \\
5)\end{array}$ & $\begin{array}{c}\text { Latin1_swedis } \\
\text { h_d }\end{array}$ & No \\
\hline username & $\begin{array}{l}\text { varchar(3 } \\
0)\end{array}$ & $\begin{array}{c}\text { Latin1_swedis } \\
\text { h_d }\end{array}$ & No \\
\hline $\begin{array}{c}\text { mobile- } \\
\text { No }\end{array}$ & $\begin{array}{l}\operatorname{varchar}(3 \\
0)\end{array}$ & $\begin{array}{c}\text { Latin1_swedis } \\
\text { h_d }\end{array}$ & Yes \\
\hline Sex & $\begin{array}{l}\operatorname{varchar}(1 \\
0)\end{array}$ & $\begin{array}{c}\text { Latin1_swedis } \\
\text { h_d }\end{array}$ & Yes \\
\hline $\begin{array}{l}\text { marital_sta } \\
\text { tu }\end{array}$ & $\begin{array}{c}\operatorname{varchar}(1 \\
0)\end{array}$ & $\begin{array}{c}\text { Latin1_swedis } \\
\mathrm{h} \_\mathrm{d}\end{array}$ & No \\
\hline $\begin{array}{l}\text { Nationalit } \\
\mathrm{y}\end{array}$ & $\begin{array}{l}\text { varchar(3 } \\
0)\end{array}$ & $\begin{array}{c}\text { Latin1_swedis } \\
\text { h_d }\end{array}$ & No \\
\hline password & $\begin{array}{l}\operatorname{varchar}(3 \\
0)\end{array}$ & $\begin{array}{c}\text { Latin1_swedis } \\
\mathrm{h} \_\mathrm{d}\end{array}$ & No \\
\hline
\end{tabular}

\subsection{Track Table}

This table contains all information about individual tracks in the music gallery area of the site. It contains information like the performer, year the track was produced, the track number, duration e.t.c. The underlined attribute is the primary key.

Table 2: Track table

\begin{tabular}{|c|c|c|c|}
\hline \multicolumn{1}{|c|}{ Field } & Type & Collation & Attributes \\
\hline id & bigint(25) & $\begin{array}{c}\text { Latin1_swedish } \\
\text { d }\end{array}$ & No \\
\hline $\begin{array}{c}\text { Performer_i } \\
\text { d }\end{array}$ & $\operatorname{int}(11)$ & $\begin{array}{c}\text { Latin1_swedish } \\
\text { d }\end{array}$ & No \\
\hline Album_id & int(11) & $\begin{array}{c}\text { Latin1_swedish } \\
\text { d }\end{array}$ & No \\
\hline Track_no & Smallint(6) & $\begin{array}{c}\text { Latin1_swedish } \\
\text { d }\end{array}$ & No \\
\hline name & $\begin{array}{c}\text { varchar(20 } \\
\text { 0) }\end{array}$ & $\begin{array}{c}\text { Latin1_swedish } \\
\text { d }\end{array}$ & No \\
\hline duration & varchar(6) & $\begin{array}{c}\text { Latin1_swedish } \\
\text { d }\end{array}$ & Yes \\
\hline Last_played & varchar(20) & $\begin{array}{c}\text { Latin1_swedish } \\
\text { d }\end{array}$ & Yes \\
\hline $\begin{array}{l}\text { Time_playe } \\
\text { d }\end{array}$ & $\operatorname{int}(11)$ & $\begin{array}{c}\text { Latin1_swedish } \\
\text { d }\end{array}$ & No \\
\hline year & $\operatorname{varchar(4)}$ & $\begin{array}{c}\text { Latin1_swedish } \\
\text { d }\end{array}$ & No \\
\hline
\end{tabular}

\subsection{Queue Table}

This table contains the tracks waiting in the queue to be played. It contains information like queue id, user name, and track id. The underlined attribute is the table's primary key

Table 3: Queue table

\begin{tabular}{|c|c|c|c|}
\hline Field & Type & Collation & Attributes \\
\hline queueid & bigint(20) & $\begin{array}{c}\text { Latin1_swedish_ } \\
\text { d }\end{array}$ & No \\
\hline usert_name & Varchar(80) & $\begin{array}{c}\text { Latin1_swedish_ } \\
\text { d }\end{array}$ & No \\
\hline track_id & bigint(25) & & No \\
\hline
\end{tabular}

\subsection{Performer Table}

This table contains the all information on the performers of various tracks the database. It contains performer's id, performer's name and biography. The underlined attribute is the primary key.

Table 4: Performer

\begin{tabular}{|c|c|c|c|c|}
\hline $\begin{array}{l}\text { fiel } \\
\text { d }\end{array}$ & type & $\begin{array}{l}\text { collatio } \\
\text { n }\end{array}$ & $\begin{array}{l}\mathbf{N} \\
\mathbf{u} \\
\mathbf{l} \\
\mathbf{l}\end{array}$ & $\begin{array}{l}\text { D } \\
\text { ef } \\
\text { au } \\
\text { lt }\end{array}$ \\
\hline pid & $\begin{array}{l}\operatorname{int}(11 \\
)\end{array}$ & & $\begin{array}{l}\mathbf{N} \\
\mathbf{o}\end{array}$ & $\begin{array}{l}\mathbf{N} \\
\text { on } \\
\mathbf{e}\end{array}$ \\
\hline $\begin{array}{l}\text { pna } \\
\text { me }\end{array}$ & $\begin{array}{l}\text { varch } \\
\operatorname{ar}(20 \\
0)\end{array}$ & $\begin{array}{l}\text { latin1_s } \\
\text { wedish_ } \\
\text { d }\end{array}$ & $\begin{array}{l}\mathbf{N} \\
\mathbf{0}\end{array}$ & $\begin{array}{l}\mathbf{N} \\
\text { on } \\
\text { e }\end{array}$ \\
\hline
\end{tabular}




\begin{tabular}{|c|c|c|c|c|}
\hline $\begin{array}{r}\text { bio } \\
\text { sh } \\
\text { ort }\end{array}$ & int & $\begin{array}{l}\text { latin1_s } \\
\text { wedish_ } \\
\text { d }\end{array}$ & $\begin{array}{l}\mathrm{Y} \\
\mathrm{e} \\
\mathrm{S}\end{array}$ & $\begin{array}{l}\mathbf{N} \\
\text { ull }\end{array}$ \\
\hline $\begin{array}{l}\text { bio } \\
\text { _lo } \\
\text { ng }\end{array}$ & int & $\begin{array}{l}\text { latin1_s } \\
\text { wedish_ } \\
\text { d }\end{array}$ & $\begin{array}{l}\mathbf{Y} \\
\mathrm{e} \\
\mathrm{S}\end{array}$ & $\begin{array}{l}\mathbf{N} \\
\text { ull }\end{array}$ \\
\hline
\end{tabular}

\subsection{Fav_Shares Table}

This table contains a list of all tracks shared by various users with other users. It contains the id, the owner's id, fav name the share id e.t.c. The underlined attribute is the primary key.

Table 5: Fav_Shares

\begin{tabular}{|c|c|c|c|c|}
\hline $\begin{array}{l}\text { fiel } \\
\text { d }\end{array}$ & type & $\begin{array}{l}\text { collatio } \\
\text { n }\end{array}$ & $\begin{array}{l}\mathbf{N} \\
\mathbf{u} \\
\mathbf{l} \\
\mathbf{l}\end{array}$ & $\begin{array}{l}D \\
\text { ef } \\
\text { au } \\
\text { lt }\end{array}$ \\
\hline id & $\begin{array}{l}\operatorname{int}(1 \\
1)\end{array}$ & & $\begin{array}{l}\mathbf{N} \\
\mathbf{0}\end{array}$ & $\begin{array}{l}\mathbf{N} \\
\text { on } \\
\mathbf{e}\end{array}$ \\
\hline $\begin{array}{l}\text { ow } \\
\text { ner } \\
\text { _id }\end{array}$ & $\begin{array}{l}\operatorname{int}(1 \\
1)\end{array}$ & & $\begin{array}{l}\mathbf{N} \\
\mathbf{0}\end{array}$ & 0 \\
\hline $\begin{array}{l}\text { fav } \\
\text { na } \\
\text { me }\end{array}$ & $\begin{array}{l}\text { Varc } \\
\text { har }(8 \\
\text { 0) }\end{array}$ & $\begin{array}{l}\text { latin1_s } \\
\text { wedish_ } \\
\text { d }\end{array}$ & $\begin{array}{l}\mathbf{N} \\
\mathbf{0}\end{array}$ & $\begin{array}{l}\mathbf{N} \\
\text { ull }\end{array}$ \\
\hline $\begin{array}{l}\text { sha } \\
\text { re_i } \\
\text { d }\end{array}$ & $\begin{array}{l}\operatorname{Int}(1 \\
1)\end{array}$ & & $\begin{array}{l}\mathbf{N} \\
\mathbf{0}\end{array}$ & 0 \\
\hline
\end{tabular}

\subsection{Fav Table}

This table contains all favorite user tracks with the track numbers, performers, duration, and user id e.t.c. The underlined attribute is the primary key.

Table 6:Fav

\begin{tabular}{|c|c|c|c|c|}
\hline field & type & collatio & N & D \\
& & n & ef \\
& & & l & a \\
& & & l & ul \\
& & & & $\mathbf{t}$ \\
\hline id & $\operatorname{int}(1$ & & $\mathbf{N}$ & $\mathbf{N}$ \\
& $\mathbf{1})$ & & $\mathbf{0}$ & $\mathbf{0}$ \\
& & & & $\mathbf{n}$ \\
\hline
\end{tabular}

\begin{tabular}{|c|c|c|c|c|}
\hline & & & & $\mathbf{e}$ \\
\hline $\begin{array}{l}\text { track } \\
\text { _id }\end{array}$ & $\begin{array}{l}\operatorname{int}(1 \\
1)\end{array}$ & & $\begin{array}{l}\mathbf{N} \\
\mathbf{0}\end{array}$ & 0 \\
\hline $\begin{array}{l}\text { perfo } \\
\text { mer_ } \\
\text { id }\end{array}$ & $\begin{array}{l}\text { varc } \\
\text { har }(8 \\
0)\end{array}$ & $\begin{array}{l}\text { latin1_- } \\
\text { swedis } \\
\text { h_d }\end{array}$ & $\begin{array}{l}\mathbf{Y} \\
\mathbf{e} \\
\mathbf{S}\end{array}$ & $\begin{array}{l}\mathbf{N} \\
\text { ul } \\
\mathbf{l}\end{array}$ \\
\hline $\begin{array}{l}\text { albu } \\
\text { m_id }\end{array}$ & $\begin{array}{l}\operatorname{int}(1 \\
1)\end{array}$ & & $\begin{array}{l}\mathbf{Y} \\
\mathbf{e} \\
\mathbf{S}\end{array}$ & $\begin{array}{l}\mathbf{N} \\
\text { ul } \\
\text { l }\end{array}$ \\
\hline $\begin{array}{l}\text { nam } \\
\text { e }\end{array}$ & $\begin{array}{l}\text { Varc } \\
\text { har }(2 \\
00)\end{array}$ & $\begin{array}{l}\text { latin1_- } \\
\text { swedis } \\
\text { h_d }\end{array}$ & $\begin{array}{l}\mathbf{N} \\
\mathbf{0}\end{array}$ & $\begin{array}{l}\mathbf{N} \\
\text { ul } \\
\text { l }\end{array}$ \\
\hline $\begin{array}{l}\text { dura } \\
\text { tion }\end{array}$ & $\begin{array}{l}\text { Varc } \\
\text { har }(6 \\
)\end{array}$ & $\begin{array}{l}\text { latin1_- } \\
\text { swedis } \\
\text { h_d }\end{array}$ & $\begin{array}{c}\mathbf{Y} \\
\mathbf{e} \\
\mathbf{S}\end{array}$ & $\begin{array}{l}\mathbf{N} \\
\mathbf{u l} \\
\mathbf{l}\end{array}$ \\
\hline $\begin{array}{l}\text { Last } \\
\text { _pla } \\
\text { yed }\end{array}$ & $\begin{array}{l}\text { Varc } \\
\text { har }(2 \\
0)\end{array}$ & $\begin{array}{l}\text { latin1_ } \\
\text { swedis } \\
\text { h_d }\end{array}$ & $\begin{array}{l}\mathbf{N} \\
\mathbf{o}\end{array}$ & $\begin{array}{l}\mathbf{N} \\
\text { ul } \\
\text { l }\end{array}$ \\
\hline $\begin{array}{l}\text { Time } \\
\text { _pla } \\
\text { yed }\end{array}$ & $\begin{array}{l}\operatorname{int}(1 \\
1)\end{array}$ & & $\begin{array}{l}\mathbf{Y} \\
\mathrm{e} \\
\mathrm{S}\end{array}$ & $\mathbf{0}$ \\
\hline year & $\begin{array}{l}\text { varc } \\
\text { har( } 4 \\
)\end{array}$ & $\begin{array}{l}\text { latin1_- } \\
\text { swedis } \\
\text { h_d }\end{array}$ & $\begin{array}{l}\mathbf{Y} \\
\mathrm{e} \\
\mathrm{S}\end{array}$ & $\begin{array}{l}\mathbf{N} \\
\mathrm{ul} \\
\mathbf{l}\end{array}$ \\
\hline $\begin{array}{l}\text { User } \\
\text { id }\end{array}$ & $\begin{array}{l}\operatorname{int}(1 \\
1)\end{array}$ & & $\begin{array}{l}\mathbf{N} \\
\mathbf{0}\end{array}$ & 0 \\
\hline $\begin{array}{l}\text { Fav__ } \\
\text { nam } \\
\text { e }\end{array}$ & $\begin{array}{l}\text { varc } \\
\text { har }(2 \\
0)\end{array}$ & $\begin{array}{l}\text { latin1_- } \\
\text { swedis } \\
\text { h_d }\end{array}$ & $\begin{array}{l}\mathbf{N} \\
\mathbf{0}\end{array}$ & \\
\hline
\end{tabular}

\subsection{Album Table}

This table contains album names, album id, album performer, biography e.t.c. The underlined attribute is the primary key.

Table 7: Album

\begin{tabular}{|l|l|l|l|l|}
\hline field & type & collatio & N & D \\
& & $\mathbf{n}$ & $\mathbf{u}$ & ef \\
& & & $\mathbf{l}$ & $\mathbf{a}$ \\
& & & $\mathbf{l}$ & $\mathbf{u l}$ \\
& & & & $\mathbf{t}$ \\
\hline
\end{tabular}




\begin{tabular}{|c|c|c|c|c|}
\hline aid & $\begin{array}{l}\operatorname{int}(1 \\
1)\end{array}$ & & $\begin{array}{l}\mathbf{N} \\
\mathbf{o}\end{array}$ & $\begin{array}{l}\text { N } \\
\text { o } \\
\text { ne }\end{array}$ \\
\hline $\begin{array}{l}\text { Perf } \\
\text { omer } \\
\text { _id }\end{array}$ & $\begin{array}{l}\operatorname{Int}(1 \\
1)\end{array}$ & & $\mathbf{N}$ & $\mathbf{0}$ \\
\hline $\begin{array}{l}\text { nam } \\
\text { e }\end{array}$ & $\begin{array}{l}\text { varc } \\
\text { har(2 } \\
00)\end{array}$ & $\begin{array}{l}\text { latin1_s } \\
\text { wedish } \\
\text { _d }\end{array}$ & $\mathbf{N}$ & $\begin{array}{l}\text { N } \\
\text { o } \\
\text { ne }\end{array}$ \\
\hline $\begin{array}{l}\text { bio_s } \\
\text { hort }\end{array}$ & int & $\begin{array}{l}\text { latin1_s } \\
\text { wedish } \\
\text { _d }\end{array}$ & $\begin{array}{l}\mathbf{Y} \\
\mathbf{e} \\
\mathbf{s}\end{array}$ & $\begin{array}{l}\text { N } \\
\text { ul } \\
\text { l }\end{array}$ \\
\hline $\begin{array}{l}\text { bio_l } \\
\text { ong }\end{array}$ & int & $\begin{array}{l}\text { latin1_s } \\
\text { wedish } \\
\text { _d }\end{array}$ & $\begin{array}{l}\mathbf{Y} \\
\mathbf{e} \\
\mathbf{S}\end{array}$ & $\begin{array}{l}\text { N } \\
\text { ul } \\
\text { l }\end{array}$ \\
\hline
\end{tabular}

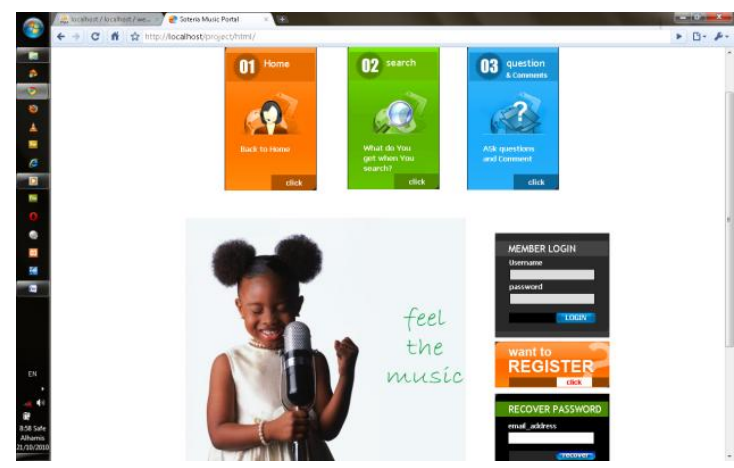

Figure 2 : Home page interface design.

Shows the home page where the specified user is to enter his/her username and password login. If the user name or the password incorrect, the page returns to the login page with a warning. Or the user clicks the want to register button in order to register or enter his/her email address in order to retrieve forgotten password.

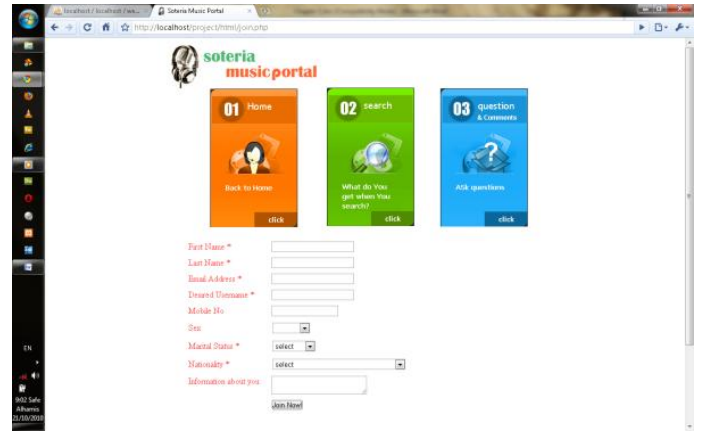

Figure 3: Registration page

This shows the registration page for users so that users can register in order to log into the site.

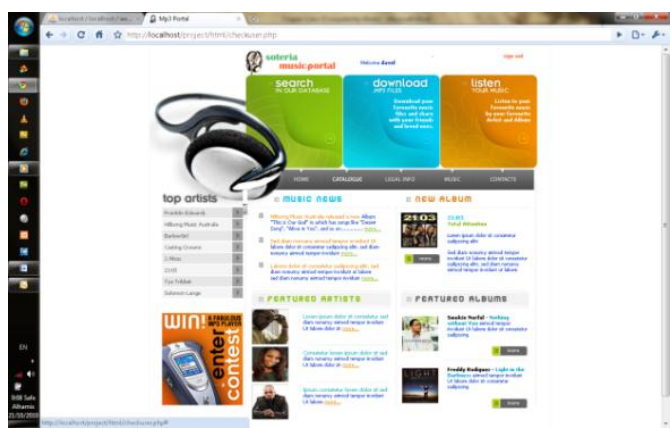

Figure 4: Users main Page

This shows the Users main page, in which only users who have registered and have passwords and have already activated their accounts can access.

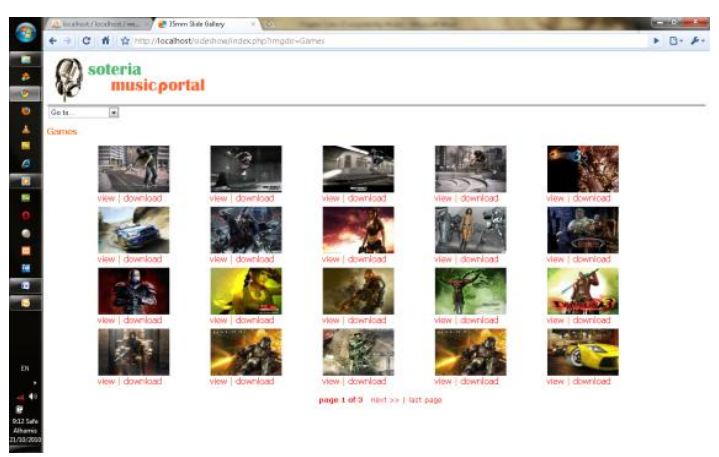

Figure 5: Image Gallery Center

Shows the image gallery center where registered users can go download wallpapers of different kinds.

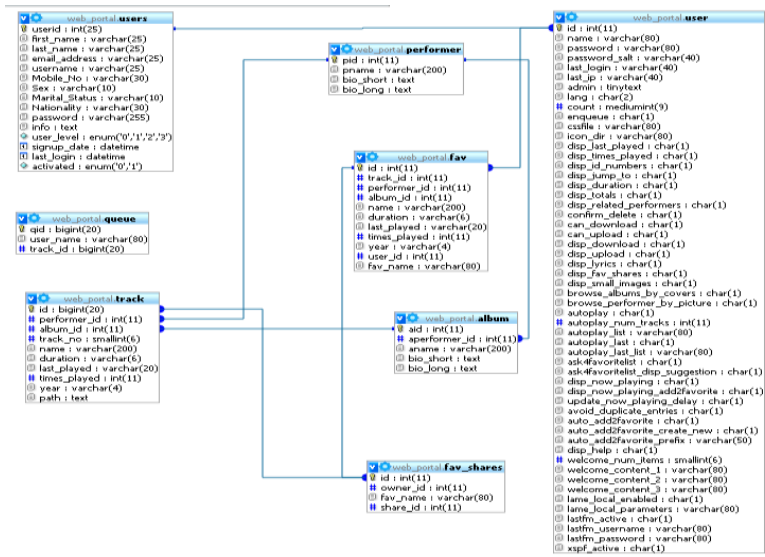

Figure 6: Physical database schemas

\section{SUMMARY AND CONCLUSION}

The Web Based Music Portal is one step towards increasing productivity and quality of service in Music.The research work the design and implementation music portal environment that could be used to download and upload music. In this research, we implemented a web-based music portal that is loosely coupled.With the implementation of this system; interested persons can download music easily.

\section{Acknowledgement}

This research is supported by Education Trust Fund of Nigeria 


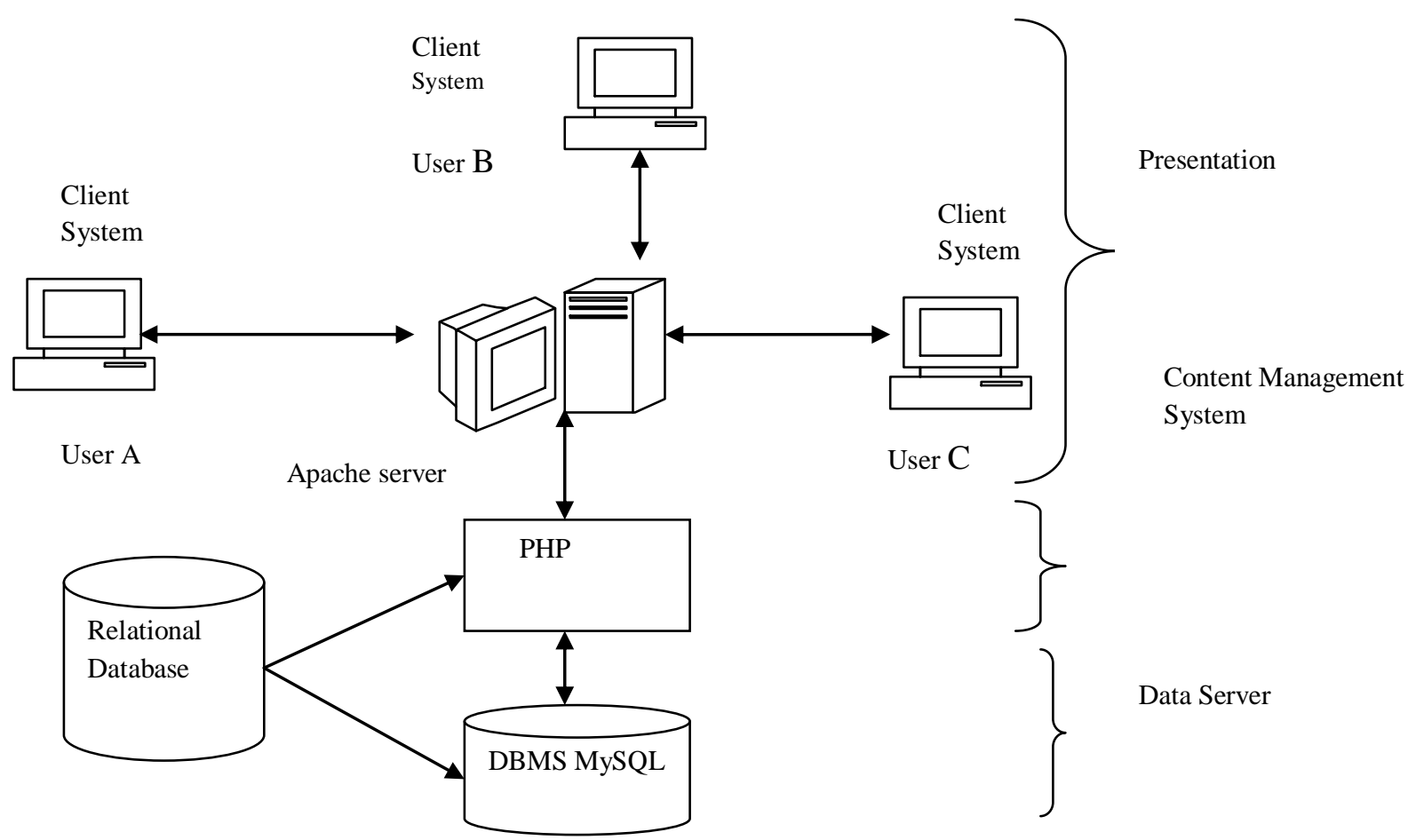

Figure 7: Online system Architecture.

\section{REFERENCES}

[1] Benslimane, Djamal; Schahram Dustdar, and Amit Sheth (2008). "Services Mashups: The New Generation of Web Applications". IEEE Internet Computing, vol. 12, no. 5. Institute of Electrical and Electronics Engineers. pp. 13-15.

[2] Cummings, Haag (2006). Management Information Systems for the Information Age. Toronto, McGraw-Hill Ryerson

[3] Ian Sommerville, 2008: Software Engineering 8th Edition,Wiley Publishing Inc, Indianapolis, Indiana. pp. 14-19,112-116.

[4] Janet Valade, 2004: PHP \& MySQL for ,Wiley Publishing Inc,2nd Edition, Indianapolis, Indiana. pp 4, 10-19.

[5] Jennifer Niederst Robbins, 2007: Learning Web Design, OReilly, New Jersey, pp. 19-29,38-45

[6] Kevin Yank, 2003: Build Your Own Database Driven Website Using PHP \& MySQL, SitePoint, Richmond, VIC Australia, pp. 7-14, 19-43.

[7] NIIT, 2004: Implementing relational databases - pp. 1A.1-1D.6 